\title{
Physical, physiological and minerals changes of different legumes types during the germination process
}

\author{
Denisa Atudorei, Silviu-Gabriel Stroe, Georgiana Gabriela Codină
}

\author{
Stefan cel Mare University of Suceava, Suceava, Romania
}

Keywords:
Legumes
Germination
Seed
Mineral

\section{Article history:}

Received 03.02.2020

Received in revised form 19.06.2020

Accepted 27.12.2020

\section{Corresponding author:}

\section{Georgiana}

Gabriela Codină

E-mail:

codina@fia.usv.ro

DOI: $10.24263 / 2304-$

974X-2020-9-4-10

\section{Abstract}

Introduction. The aim of this study was to highlight the physical and physiological changes of different types of legumes and the variation of their mineral amount during the germination process, in order to establish the optimal germination period for their use in consumption.

Materials and methods. Legumes types such as chickpea, bean, lentil, lupine, and soybean were germinated in a plant growth chamber Binder KBW/KBWF 240. To highlight the physical and physiological changes of legumes during the germination process, a Motic SMZ-140 Stereomicroscope was used. In order to highlight the variation of the amount of mineral substances during the germination process, a Shimadzu EDX-900HS was used.

Results and discussion. The protein content of the analyzed legumes varied between 19.40 and $40.34 \%$ the highest amount being for soy and the lowest one for chickpea sample. All the samples presented good viability for germination, the highest one being for lentil of $90 \%$ for which was also recorded the highest germination energy value. The image obtained clearly showed the development of the component parts of the germs: the radicle and the plumule which increases during the germination process, when the seed began to synthesize chlorophyll and when the root began to develop. According to their development the maximum germination time were of 10 days for lentil and lupin and of 9 days for chickpea, bean and soybean. However, for their use in food consumption, the optimum germination period was established for 4 days for all the analyzed legumes samples for which except the bean sample the radicle was much higher than the legume grain size. In general, the availability of calcium and sulf was improved for all the samples in the four day of germination. The calcium increases most for chickpeas with almost six times and for lentil with three times. Reported to the ungerminated seeds the phosphor and iron increases for lentil seeds in the four day of germinations whereas for the rest of legumes decreases. Regarding potassium, magnesium and zinc elements, in general, their values decreases with the increase time of germination period.

Conclusions. By highlighting the physical and physiological changes of legumes during germination, it is easier to determine when the germination process should be stopped. The amount of many nutrients increases as a result of the germination process, and this process can have various applications in the food industry. 


\section{Introduction}

Seed germination is a complex physiological process that has as its starting point the absorption of water by seeds, and as a final point, the appearance of the root, a component part of the future plant [1]. It can be said that the seed germination is the first phase of the plant development cycle [2].

Lately, there has been a lot of interest in the germination process, regarding the food field. This is explained by several considerations. First, researchers are studying the germination process because in some industries it is desirable to combat this process because it makes food unfit for consumption. In this sense, the use of gamma radiation to inhibit the germination of nuts [3] or wheat [4] can be exemplified as the results of various studies. Secondly, the study of the germination process is of interest due to the fact that recently there has been an increase in the consumption of germs of different seeds. This is desirable due to the positive effects of germination on the grains subjected to this process. Different studies show that germination leads to increase bioavailability of minerals in seeds $[5,6,7,8]$, the amount of phenolic compounds [9, 10], flavonoids $[11,12]$, the amount of amino acids (Gamma Aminobutyric Acid and essential amino acids) [13, 14, 15], vitamins $[16,17,18]$. It has also been shown that germination contributes to the activation of hydrolytic enzymes, which result in improved digestion of certain compounds, such as proteins and starch $[19,20,21]$. This is of particular interest to people who are suffering of with various diseases of the digestive system [22]. At the same time, germination is seen as a desirable process because it has the role of decreasing the amount of antinutrients in the grain (for eg. phytic acid, which combines with various minerals and result phytates) [23, 24, 25]. Also, the interest for seed germs today is great due to the fact that they can be incorporated into the recipe of manufacturing various foods, in order to improve their nutritional profile or sensory and quality characteristics [22]. In this sense, can be list: bakery products [26, 27, 28], yogurt [29, 30, 31], biscuits [32, 33, 34], cakes [35, 36, 37] and so on.

Regardless of the purpose pursued, it is necessary to carefully monitor the parameters of the germination process (temperature, humidity, aeration, lighting), so that the germs obtained to be of a superior quality, to contain an optimal amount of nutrients (in this regard, it is recommended that the germination time should not be prolonged too much, so that the grains not to be depleted in nutrients) [9, 10, 16], the sensory characteristics (color, appearance, smell, taste) should not be adversely affected and the microbial load should not exceed that indicated by standards in force $[26,28]$, so that the health of consumers not to be jeopardized by any microorganisms that have developed or by toxins that have been released along the way $[22,23]$.

Depending on the field of use of the germs obtained, the germination parameters must be chosen in such a way that what is desired to be obtained (optimal enzymatic activity or inhibition of antinutritive factors, for example) to be successful [37]. In this sense, it is necessary to carefully study the literature that indicates clear suggestions in this regard. Highlighting the physical and physiological changes of different types of vegetables during the germination process is desirable so that the germination process can be optimally conducted, so that the germs obtained to be of superior quality and thus can serve with success for the purpose for which it is intended to be used [20,22].

According to our acknowledgment, no comparative study has been made on so many types of legumes seeds during the entire germination period on their physical and physiological changes on modern device such as Stereomicroscope one. Also, no other study has been made on a comparative analysis of minerals availability during the 0,2 and 4 germination days between chickpea, bean, lentil, lupine, and soybean type. 
The aim of this study was to highlight the physical and physiological changes of different types of legumes during the germination process, changes that are correlated with the determination of the size of the developed parts during germination (plumule and radicle) and to highlight the variation of mineral content during the germination process, of which amount was compared to those of the ungerminated seeds. Thus, will be highlighted the optimal germination time, so that the germs to present superior quality for consumption.

\section{Materials and methods}

\section{Materials}

The grain legumes seeds used were: chickpea (Cicer arietinium L.), bean (Phaseolus vulgaris), lentil (Lens culinaris Merr.), lupine (Lupinus albus) and soybean (Glycine max L.). All the grain legumes seeds were cultivated in Romania and were not genetically modified.

\section{Grain legumes seeds analysis}

The grain legumes seeds were analyzed for its physical-chemical properties according to the International standard methods as follows: the hectoliter weight was determined according to the ISO 7971-1:2009, the moisture content of legumes seeds were determined according to ISO 7700-1:2008, the seeds viability was determined by usual inspection of cut seeds through tetrazolium staining [38], the seeds germination capacity was determined according to ISTA (2006) standard [39], and the protein content was determined according to EN ISO 20483:2006.

\section{Grain legumes seeds germination process}

For legumes seeds germination, a Binder KBW/KBWF germination chamber was used. The germination process was carried out to a maximum germination period of 9 days for soybeans, beans and chickpeas and for 10 days for lupine and lentils in accordance with the conditions provided by the ISTA (2006) standard [39]. The germination was made on dark conditions to a temperature which varied between 20 and $25^{\circ} \mathrm{C}$ and to a constant humidity value of $80 \%$. The germination layer used was the filter paper.

\section{Grain legumes seeds analysis during the germination process}

In order to highlight the physical and physiological legumes seeds changes during the germination process was measured every day the size of the radicle and plumule of legumes seeds by using a Modelcraft Vernier Calliper of $125 \mathrm{~mm}$ [40]. Also, it was captured the physical and physiological changes that occur in legumes seeds during the germination process by using a Motic SMZ-140 Stereomicroscope device [41]. This allowed us to obtain detailed images that highlight the essential changes: increasing the volume of the grain due to the water absorption, degradation of the protective coating of the grain, the development of the component parts of the germs, etc. 


\section{Statistical analysis}

Data were expressed as means \pm standard deviations for triplicate determination. Statistical analysis was performed using XLSTAT statistical package (free trial version, Addinsoft, Inc. Brooklyn, NY, USA) at a significance level of p $<0.05$ [42].

\section{Results and discussion}

\section{Physical-chemical characteristics of the ungerminated legumes seeds}

The data for the physical-chemical analysis are shown in Table 1. As it may be seen, the soybean presented the highest protein content value, whereas the chickpea the lowest one. From the hectolitre point of view this value varied between 70.0 and $84.5 \mathrm{~kg} / \mathrm{hl}$ with the highest value for lentil and the lowest one for lupine seeds. The humidity value for the seeds sample was not higher than $10.9 \%$ whereas the legumes seeds capacity to germinate determined through viability and germination energy indicated the fact that lentil presented the highest capacity to germinate whereas the lupine and chickpea the lowest one.

Physical-chemical characteristics of legumes seeds

Table 1

\begin{tabular}{|c|c|c|c|c|c|}
\hline Legumes seeds & $\begin{array}{c}\text { Hectolitre } \\
\text { weight } \\
{[\mathbf{k g} / \mathbf{h}]}\end{array}$ & $\begin{array}{c}\text { Humidity } \\
{[\mathbf{\%}]}\end{array}$ & $\begin{array}{c}\text { Viability } \\
{[\mathbf{\%}]}\end{array}$ & $\begin{array}{c}\text { Germination } \\
\text { energy [\%] }\end{array}$ & $\begin{array}{c}\text { Protein } \\
\text { content }[\%]\end{array}$ \\
\hline Soy & $70.5 \pm 0.03$ & $9.8 \pm 0.01$ & $77 \pm 0.47$ & $74 \pm 0.81$ & $40.34 \pm 0.01$ \\
\hline Lupine & $70.0 \pm 0.02$ & $7.7 \pm 0.02$ & $52 \pm 0.81$ & $51 \pm 0.47$ & $39.90 \pm 0.03$ \\
\hline Chickpea & $73.5 \pm 0.01$ & $10.3 \pm 0.01$ & $50 \pm 0.81$ & $52 \pm 0.47$ & $19.40 \pm 0.04$ \\
\hline Bean & $70.8 \pm 0.04$ & $10.9 \pm 0.01$ & $73 \pm 0.47$ & $70 \pm 0.81$ & $22.60 \pm 0.02$ \\
\hline Lentil & $84.5 \pm 0.02$ & $7.6 \pm 0.01$ & $90 \pm 0.47$ & $88 \pm 0.81$ & $28.69 \pm 0.03$ \\
\hline
\end{tabular}

Physical, physiological and minerals changes during the germination process of different types of legumes seeds

The physical and physiological changes of different types of legumes were presented below, during every day of germination process (from day 1 to 9 , respectively to 10 days of germination process depending on the legumes type). For 0,2 and 4 days of germination process it was determined the amount of mineral elements such as calcium, iron, phosphorus, sulfur, zinc, manganese, and potassium from the legumes seeds by using a spectrometer Shimadzu EDX-900HS (Shimadzu Corporation, Kyoto, Japan) device. It was established the variation of legumes types during the 4 days of germination due to the fact that according to the physical changes during the germination process was the optimum day for their use in food consumption. Also different studies has been reported that at this time of germination process the enzymatic activity of legumes are in a high amounts $[43,44,45]$ and if the germination period exceeded too much the amount of nutrients begin to decreases which is not a desirable fact [8, 46, 47, 48]. 


\section{Physical and physiological changes of the lentil during germination}

Figure 1 shows the changes that occur during germination process in the lentil seeds, during the 10 days of germination. At the same time, it can be seen the variation of the size of the component parts (radicle and plumule) during the ten days of germination. Thus, on the first day of germination there is an increase in the volume of the lentil seed, as a result of the absorption of water needed in the subsequent germination process; the absorption of water being done through free pores and capillaries. Water absorption is done to hydrate the grain, in order to stop the grain dormancy [49]. In the literature, it is considered that the optimum moisture content for germination is $75-80 \mathrm{~g}$ of water per $100 \mathrm{~g}$ of dry matter [50]. During the other 9 days of germination, it can be seen the changes that occur: on the second day the radicle begins to develop, and from the third day, it can be seen the plumule. The dimensions of these components increase from day to day.

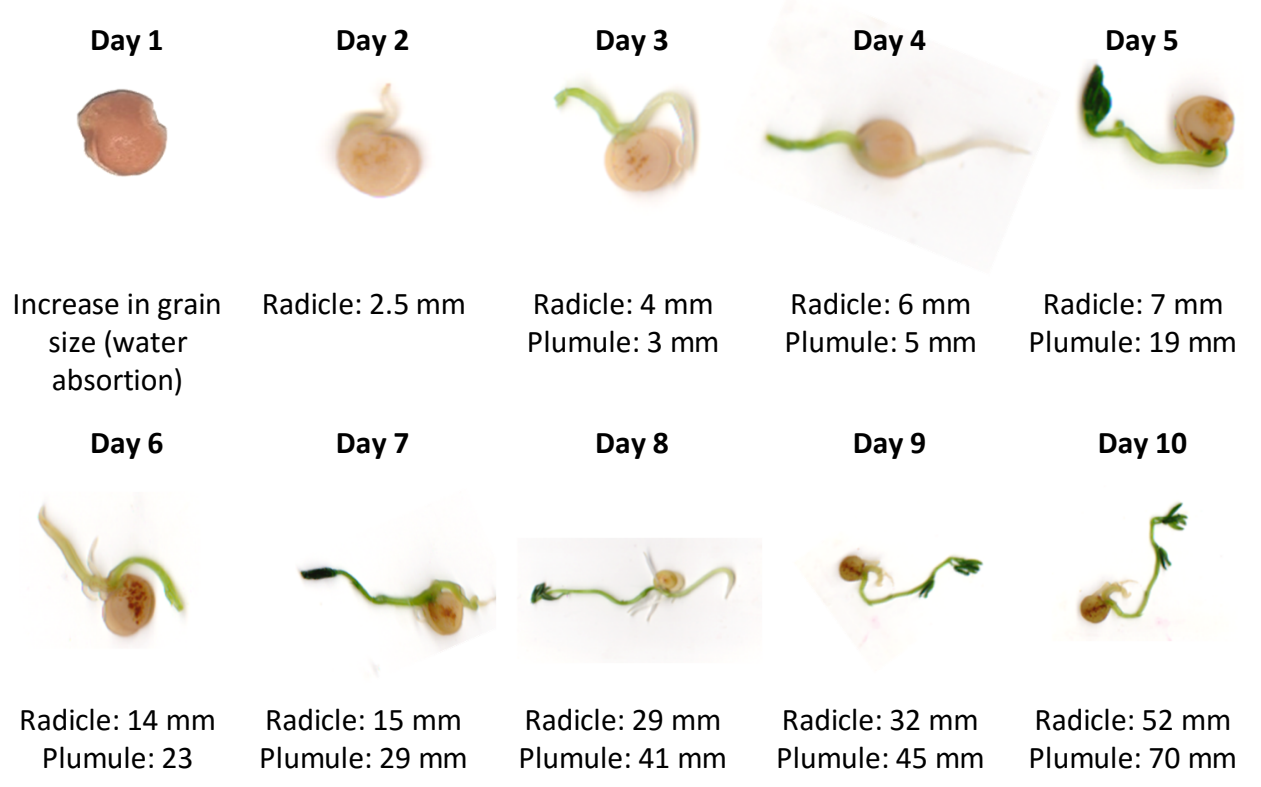

Figure 1. Physical and physiological changes of the lentil seeds during the germination process

Images captured and presented in Figure 2 with the Motic SMZ-140 stereomicroscope showed the grain in a dorsal, facial, transverse, and cross-sectional position. In the literature, the stereomicroscope has been used successfully to study the germination phenotype [51]. From these images, it can be seen that the development of the root begins from day one. The chlorophyll is found in cellular organs called chloroplasts and has an important role in the process of photosynthesis. It helps to capture the light needed in the photolysis of water molecules, in order to assimilate carbon in the other stages of photosynthesis $[52,53]$. In the other stages, on days 7-10, it is observed that the root of the future plant grows more and more, so that the plant can be prepared for the absorption of nutrients and water from the soil, a process in which the root has an essential role $[54,55]$. 

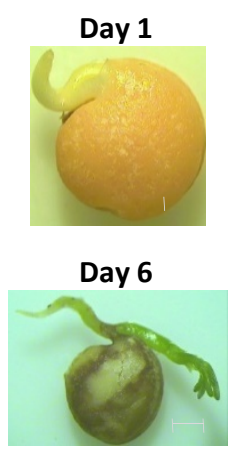

Day 2

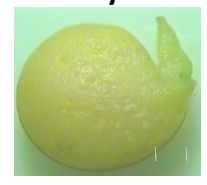

Day 7

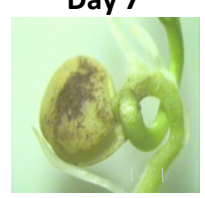

Day 3

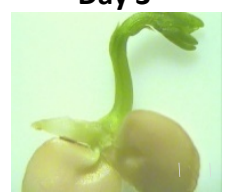

Day 8

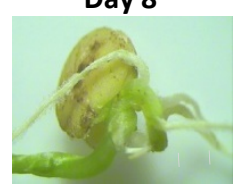

Day 4

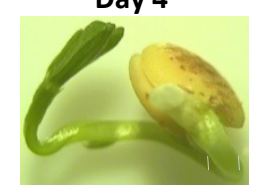

Day 9

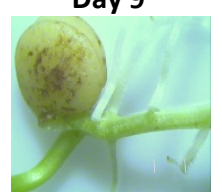

Day 5

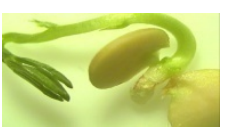

Day 10

Figure 2. Physical and physiological changes of the lentil, captured with the Motic SMZ-140 Stereomicroscope

\section{Physical and physiological changes of the bean, during germination}

Figures 3 and 4 showed the changes that occur during germination process in the bean seed, during the 9 days of germination.
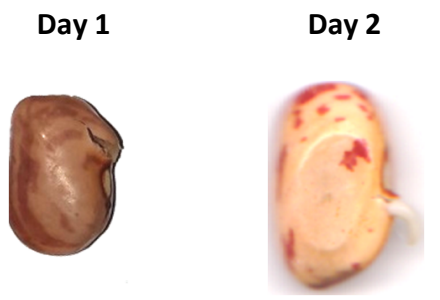

Increase in grain size (water absortion)

Radicle: $3.5 \mathrm{~mm}$;

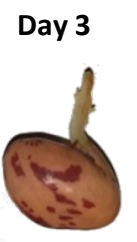

Day 4

Day 5
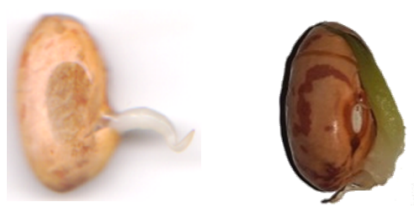

Radicle: 7 mm

Radicle: $13 \mathrm{~mm}$

Radicle: $27 \mathrm{~mm}$
Day 6

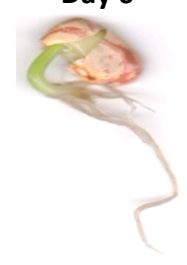

Radicle: $68 \mathrm{~mm}$
Day 7

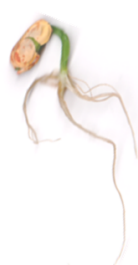

Day 8

Day 9

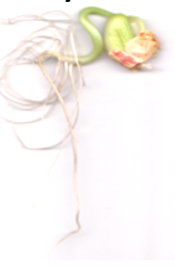

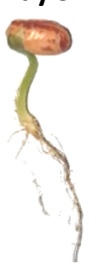

Figure 3. Physical and physiological changes of the bean seeds during the germination process 
It can be seen that on day 1 of germination, as in the case of lentils, the grain increased in volume due to the absorption of water needed for the next steps. Water plays an important role in the germination process. During germination, it is very important to keep the humidity constant because a water deficit will cause the degradation of the germ membrane and their integrity [62]. As studies suggested, the presence of water is necessary to initiate the germination process [63]. In the next stages of germination, days 2-5, the development of the radicle is observed. Starting with the sixth day, the appearance of the root of the future plant is observed. It is also observed, starting with the fifth day, the synthesis of chlorophyll, a pigment of significant importance in the subsequent process of photosynthesis, a process that ensures the correct development of the plant.

Figure 4 highlights in more detail the physical and physiological changes that occurred during the germination process. Images captured using the Motic SMZ-140 stereomicroscope showed the grain in a dorsal, facial, transverse, and cross-sectional position.

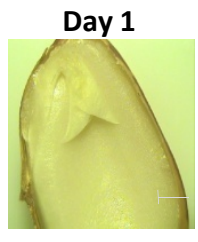

Day 6

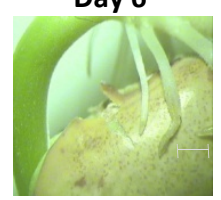

Day 2

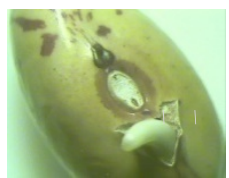

Day 7

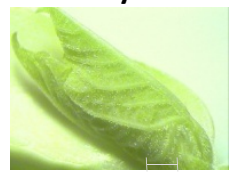

Day 3

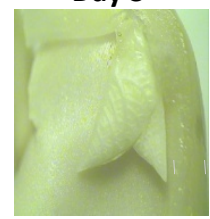

Day 8

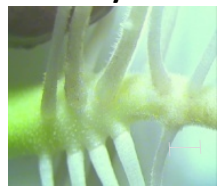

Day 4

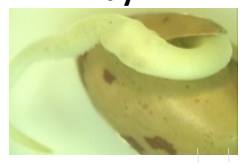

Day 9

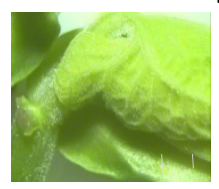

Day 5
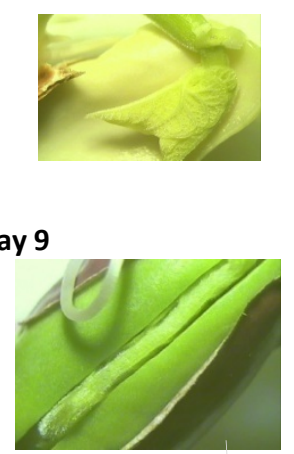

Figure 4. Physical and physiological changes of the beans, captured with the Motic SMZ-140 Stereomicroscope

\section{Physical and physiological changes of lupine during germination}

Figures 5 and 6 showed the changes that occur during germination in the lupine grain during the 10 days of germination period. In the case of lupine, it can be seen that on days 2 , 3 and 4 takes place the development of the radicle, up to a size of $11 \mathrm{~mm}$. From the 5 th day onwards, chlorophyll is synthesized. From the 8th day, the appearance of the root of the future plant is observed. 


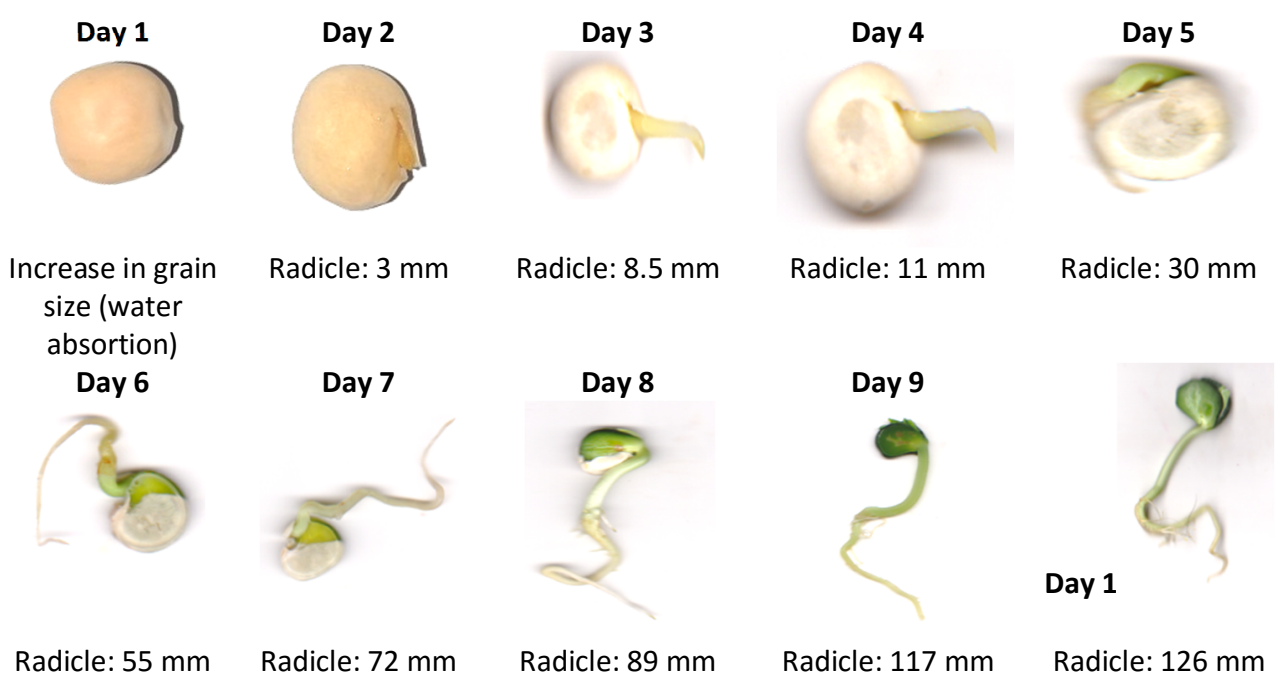

Figure 5. Physical and physiological changes of the lupine seeds during the germination process

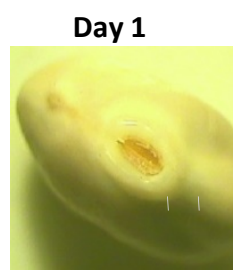

Day 6

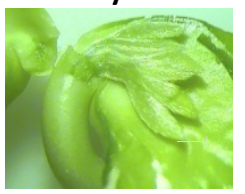

Day 2

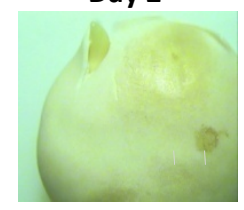

Day 7

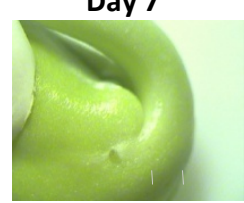

Day 3

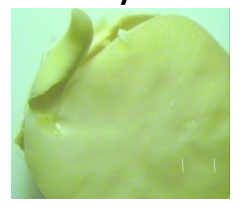

Day 8

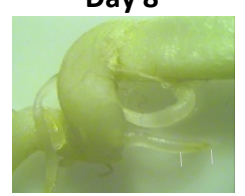

Day 4

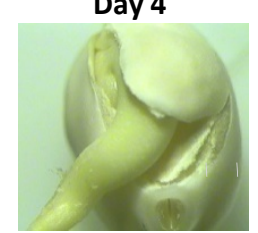

Day 9

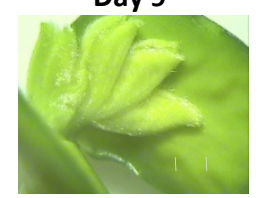

Day 5

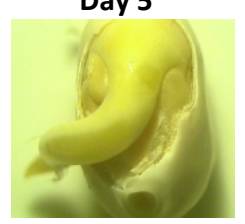

Day 10

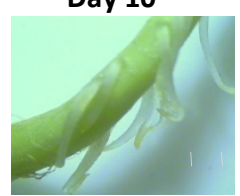

Figure 6. Physical and physiological changes of the lupine, captured with the Motic SMZ-140 Stereomicroscope

\section{Physical and physiological changes of chickpeas during germination}

The changes that occur during germination in the chickpea, during the 9 days of germination, can be seen in Figures 7 and in Figures 8. Thus, the development of the radicle in the case of chickpea begins on the second day. Starting with the sixth day, the appearance and development of the plumule and the synthesis of chlorophyll are observed. On the ninth day, the radicle has a length of $130 \mathrm{~mm}$ and the plumule, $58 \mathrm{~mm}$. The images from figure 8 captured to the dorsal, facial and transverse seed position, facilities the observing in detail the development of the leaves and the root (days 6-9). 
Day 1

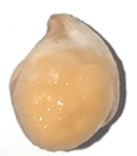

Increase in grain size (water absortion)

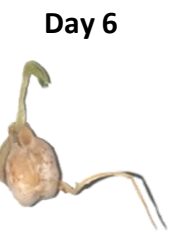

Radicle: $21 \mathrm{~mm}$ Plumule: $12 \mathrm{~mm}$
Day 2

Day 3

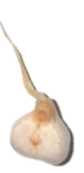

Radicle: $3 \mathrm{~mm}$

Day 7

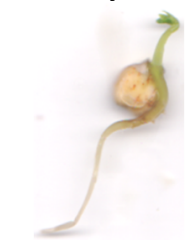

Radicle: $47 \mathrm{~mm}$ Plumule: $21 \mathrm{~mm}$
Day 4

Day 5

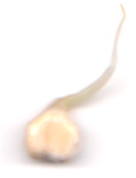

Radicle: $16 \mathrm{~mm}$

Radicle: $21 \mathrm{~mm}$

Figure 7. Physical and physiological changes of the chickpeas seeds during the germination process

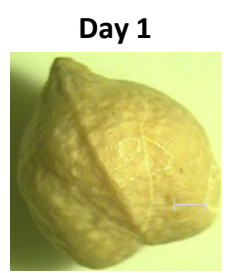

Day 6

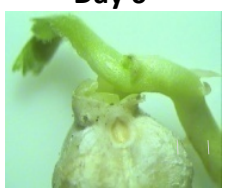

Day 2

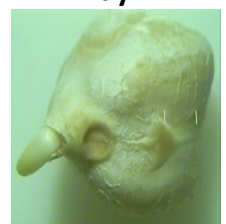

Day 7

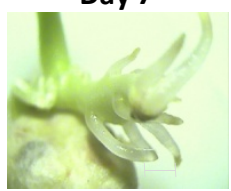

Day 3

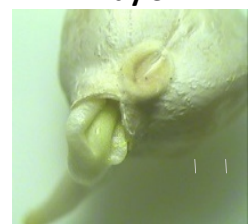

Day 8
Day 4

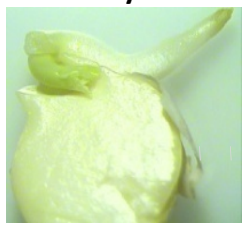

Day 9
Day 9

Radicle: $130 \mathrm{~mm}$

Plumule: $58 \mathrm{~mm}$

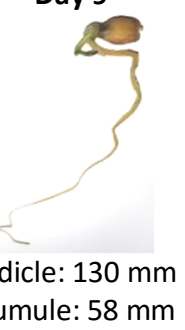



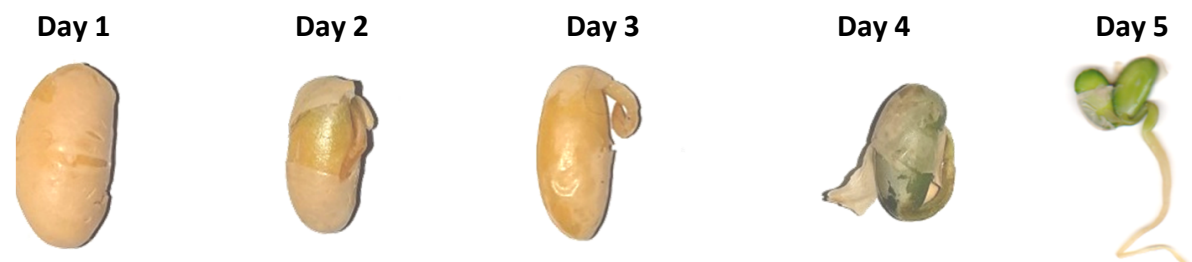

Increase in grain Radicle $3 \mathrm{~mm}$ size (water absortion)

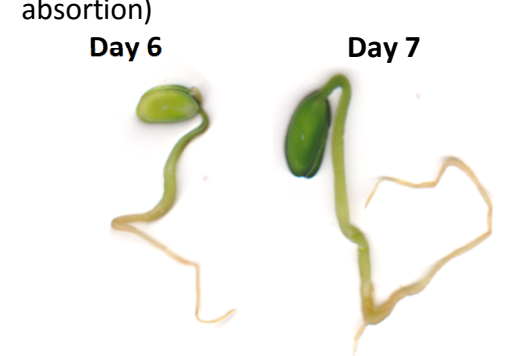

Radicle: $8 \mathrm{~mm}$

Radicle: $24 \mathrm{~mm}$

Radicle: $49 \mathrm{~mm}$
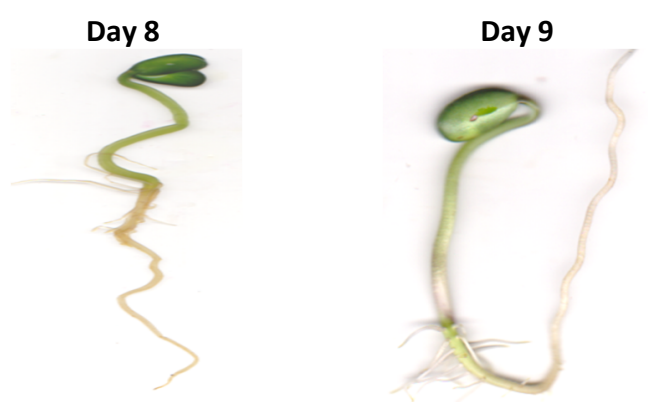

Radicle: $81 \mathrm{~mm} \quad$ Radicle: $135 \mathrm{~mm}$

Radicle: $149 \mathrm{~mm}$

Radicle: $160 \mathrm{~mm}$

Figure 9. Physical and physiological changes of the soybean seeds during the germination process
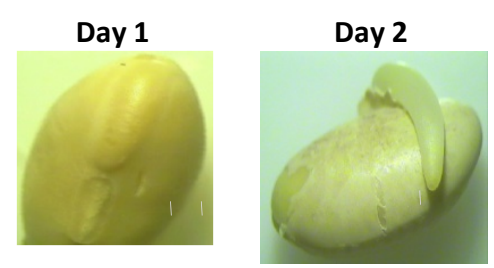

Day 6

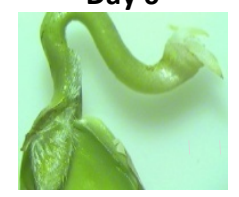

Day 7

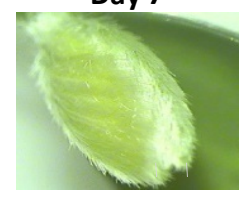

Day 3

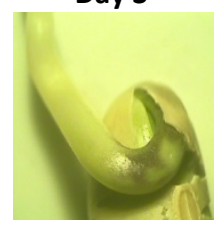

Day 8

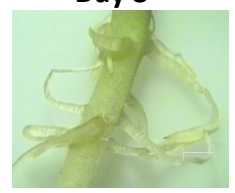

Day 4

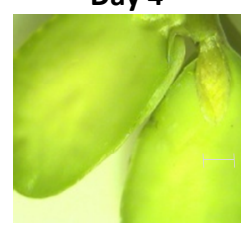

Day 9

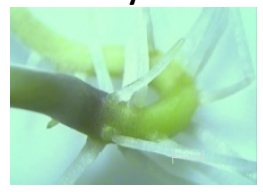

Day 5

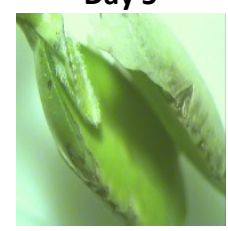

Figure 10. Physical and physiological changes of the soybean, captured with the Motic SMZ-140 Stereomicroscope 


\section{Mineral changes of the legumes seeds during the $\mathbf{4}$ days of germination period}

Figures 11-16 showed how the mineral content varies with the germination time, during day 0,2 and 4 for all five types of legumes considered in this study (lentil, bean, lupine, chickpea and soybean). It was observed that the amount of most minerals decreases with increasing germination time. From Figure 11, it can be noticed that the amount of calcium increases with increasing germination time. This is probably due to the fact that, during germination, the amount of phytic acid decreases. This is a desirable thing because phytic acid forms phytates with the minerals. At the same time, the minerals that are in bound form are released during germination [11, 56, 57]. Another reason would be that, during germination, amylases are activated. Amylases are metalloenzymes with calcium in the composition. Studies show that calcium is sometimes found bound to $\alpha$-amylases [58]. If calcium is completely lost from the structure of the enzyme, then the enzymatic activity is stopped [59]. Therefore, if the germs obtained are to be used for their enzymatic activity, the variation of the amount of calcium must be followed carefully. In the case of the enzyme, calcium has an important role in supporting the structure of $\alpha$-amylase because it interacts with negatively charged amino acid residues (aspartic and glutamic) and thus stabilizes the structure of the enzyme [60]. Calcium also plays an important role in stopping the proteolytic degradation of $\alpha$-amylase [61].

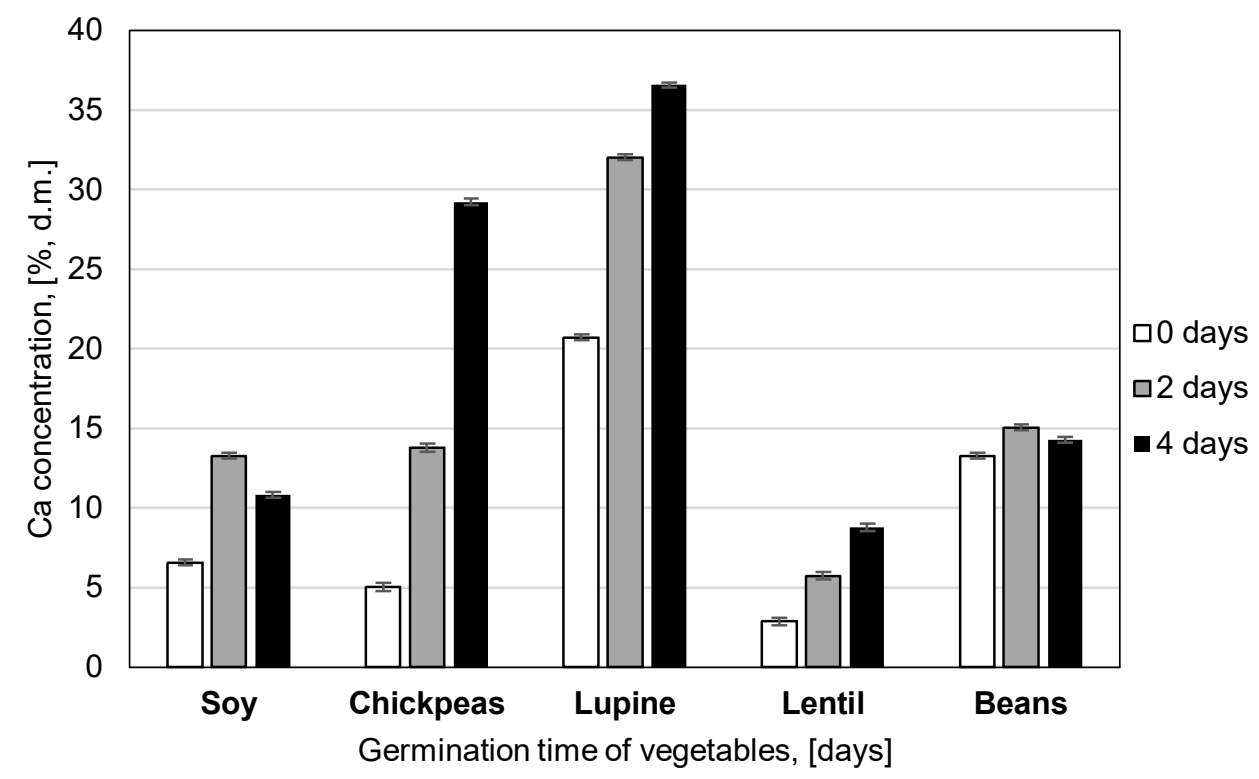

Figure 11. Variation in calcium concentration during the germination time

In Figure 12, it can be noticed, for example, that the sulfur content increases for almost all legumes types on the fourth day of germination compared to the control sample. Increasing the amount of sulfur could be attributed to the fact that plants need sulfur to grow properly [64]. Increasing the amount of sulfur in seed germs is desirable, as shown by various studies in the field $[65,66]$ because sulfur is an essential mineral in the human body and has been shown to act as an antioxidant and help fight atherosclerosis and cancerous tumors [67]. 


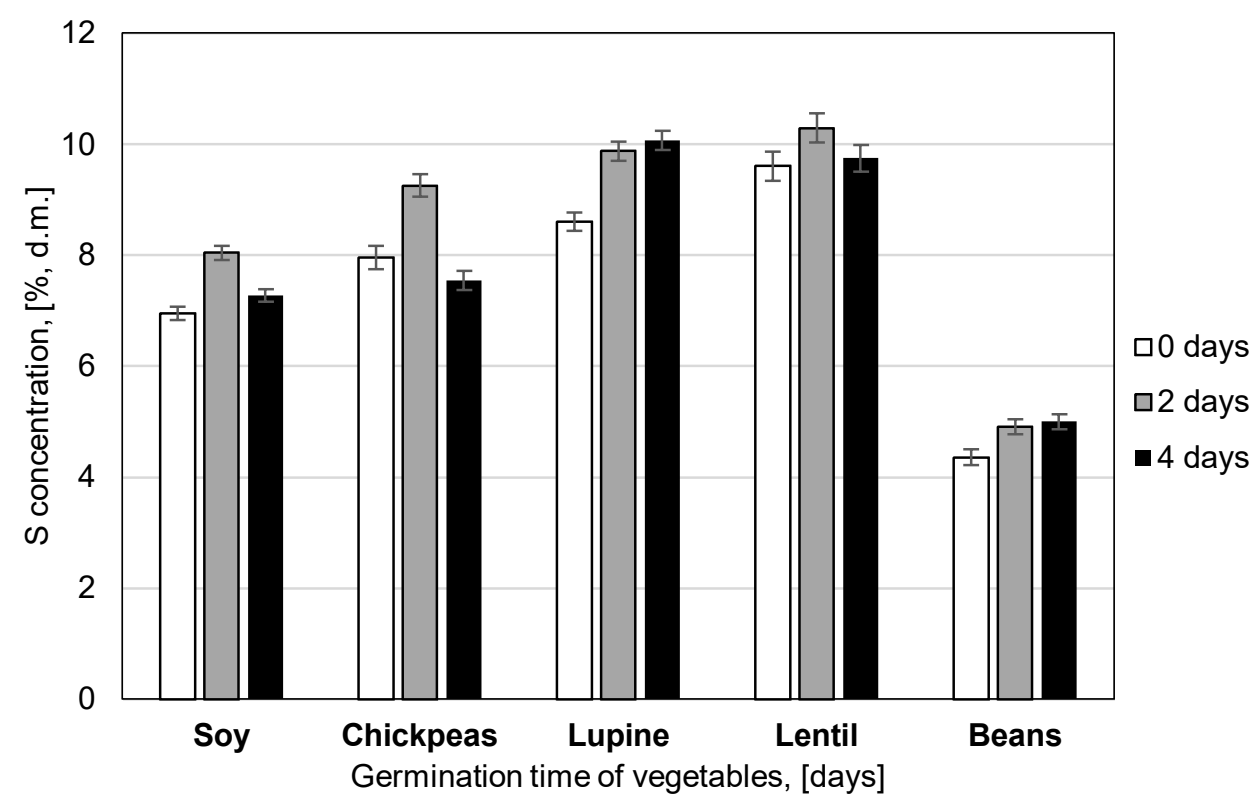

Figure 12. Variation in sulfur concentration during the germination time

The variation of the potassium content during the germination process of legumes can be seen in figure 13. Hence, it is observed that the potassium content decreases for the sample in the four day of germination compared to the control sample. This process occurs because potassium is a very important element used to develop the component parts of the future plant [68].

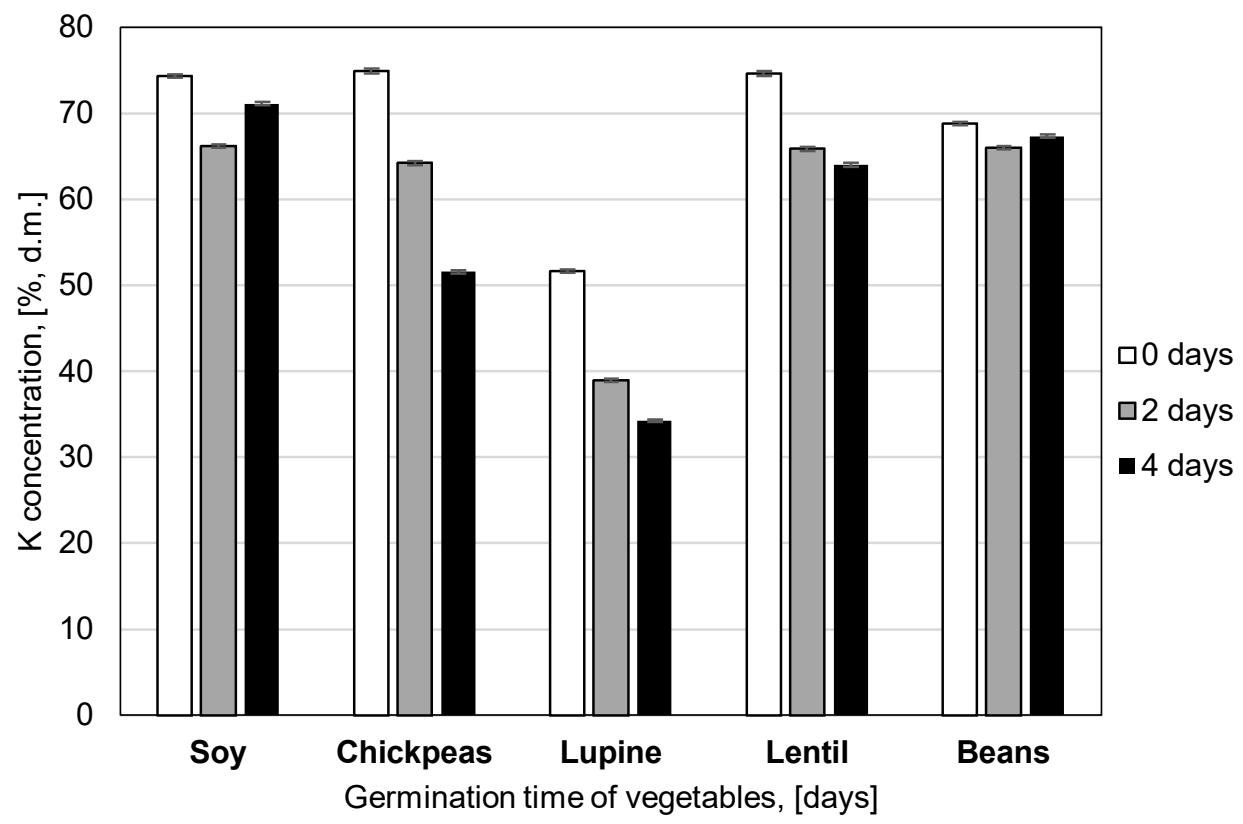

Figure 13. Variation in potassium concentration during the germination time 
In general, during the germination process, compared to the control sample the amount of phosphorus decreased. This may be due to the fact that in the germination process phosphorus is consumed for the development of the seeds components (radicle and plumule).

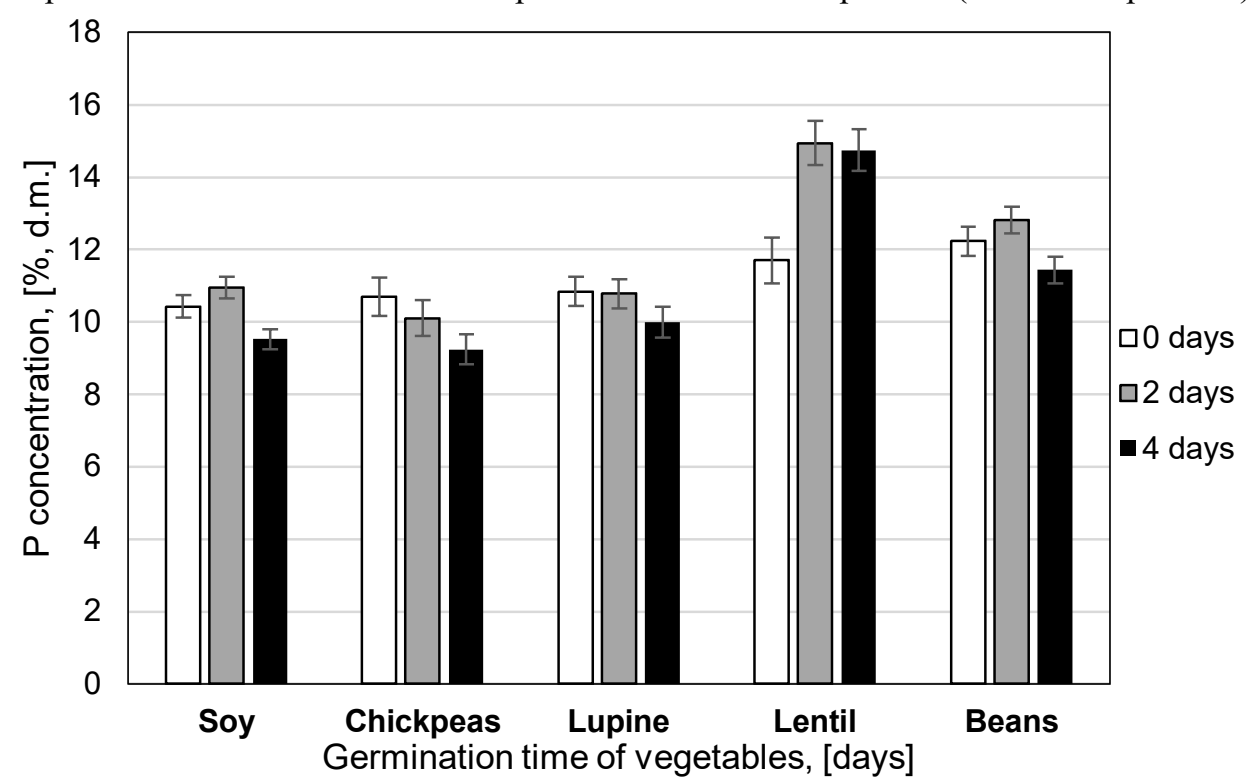

Figure 14. Variation in phosphorus concentration during the germination time

Figures 15-17 show how the concentration of mineral substances such as $\mathrm{Fe}, \mathrm{Zn}$ and Mn varied during the 4 days of germination process.

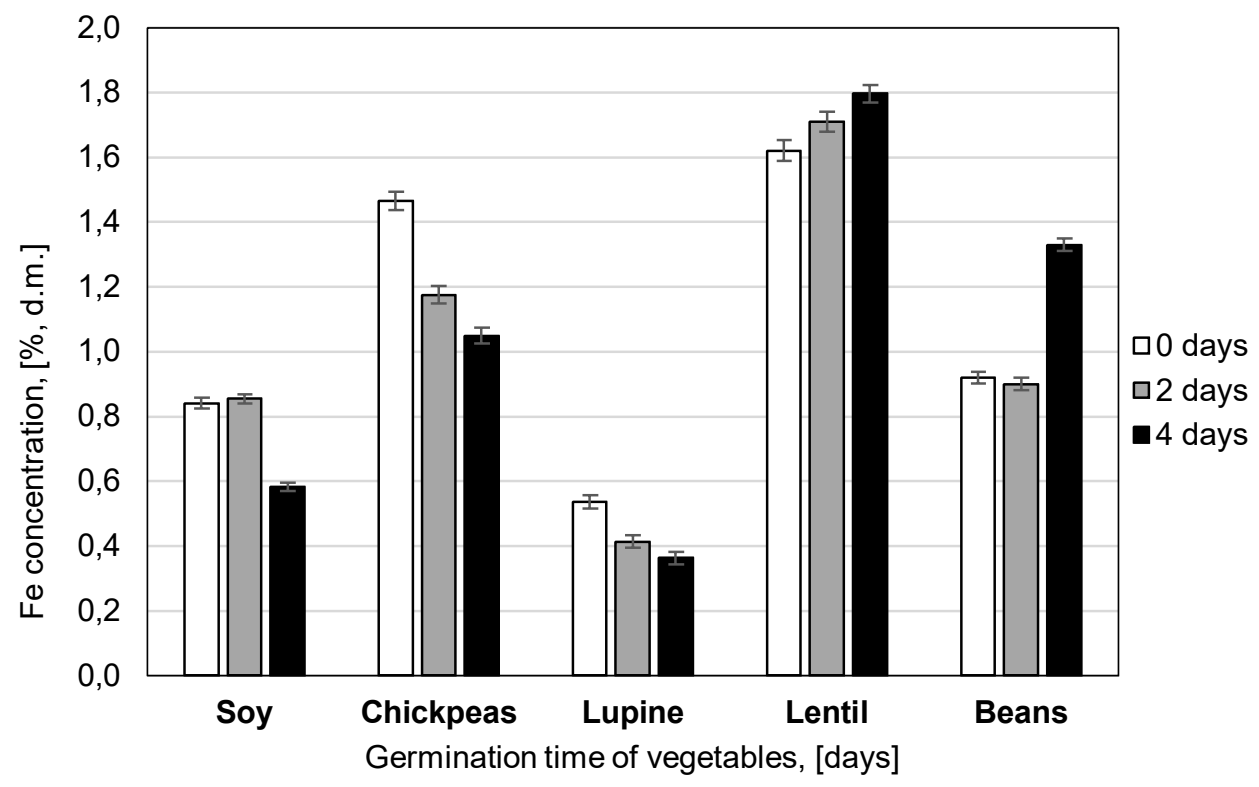

Figure 15. Variation in iron concentration during the germination time 


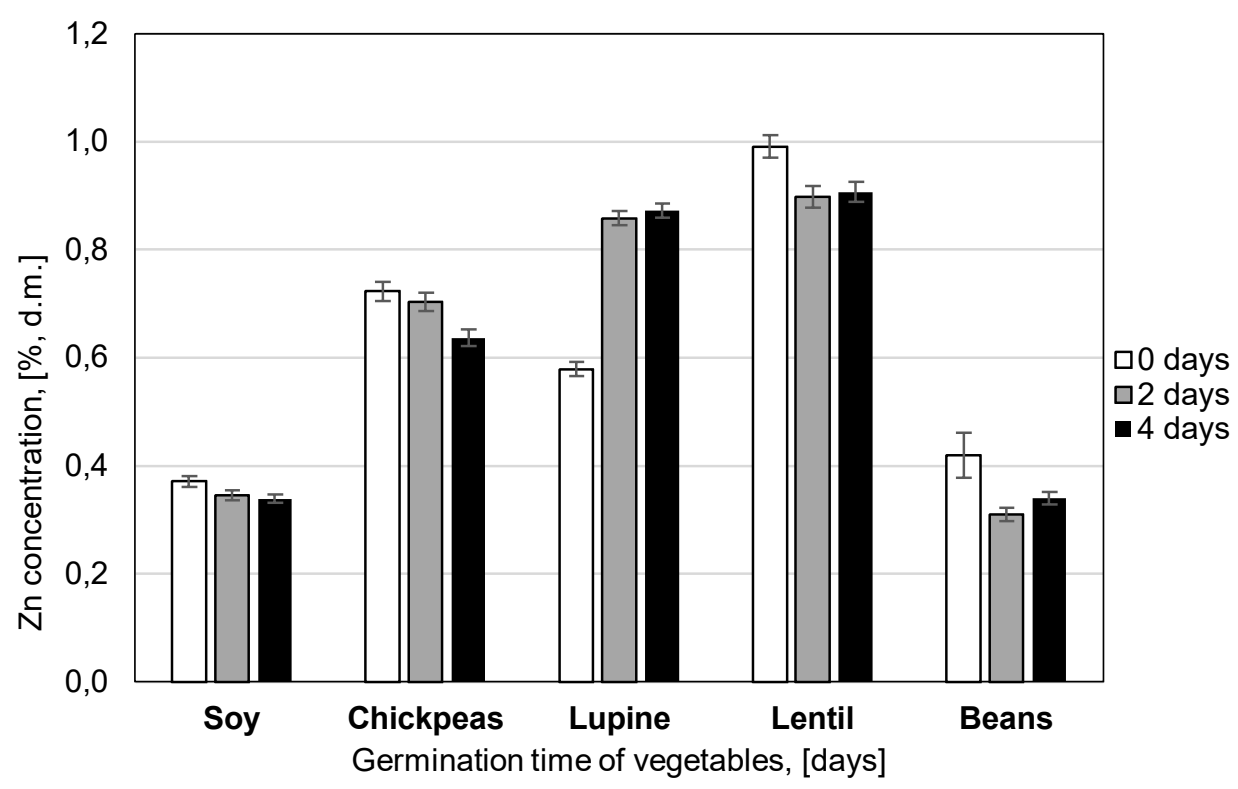

Figure 16. Variation in zinc concentration during the germination time

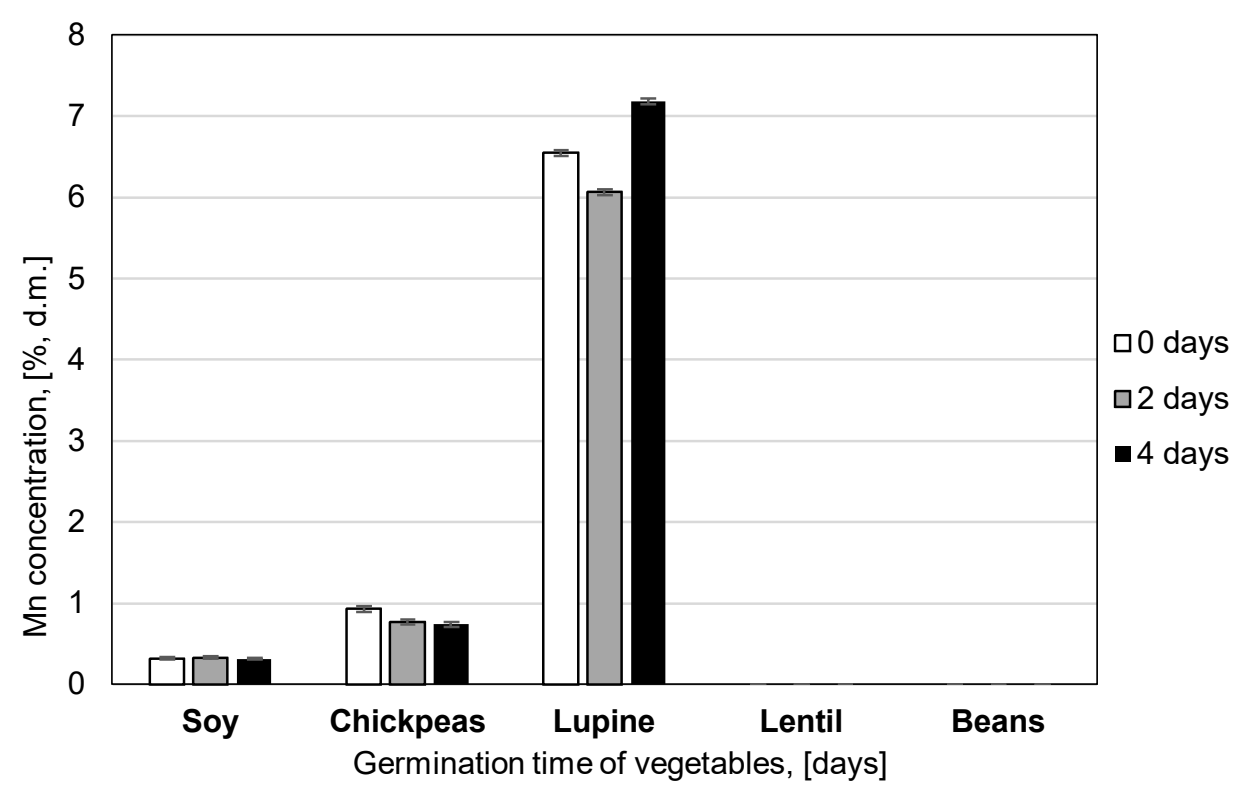

Figure 17. Variation in manganese concentration during the germination time

A decrease in iron content may be noticed to soy, chickpea and lupine to the 4 day of germination. This data are similar with those reported by others [69]. However, an increase of iron may be noticed to beans and lentil in the 4 day of germination period. Also the zinc 
and manganese increases or decreases depending on the legumes type. Due to the fact that germination increases the concentration of some mineral substances, it can be said that this process can be used successfully to improve the nutritional profile of germinated grains or foods in which the germs will be incorporated in some mineral elements depending on the legumes type [71-77].

\section{Conclusions}

1. The physical and physiological changes of legumes types chickpea, bean, lentil, lupine, and soybean shown that for all the analyzed samples the four days of germination period may be an optimum one for their use in food consumption.

2. During the germination period, the amount of mineral substances varies differently for each type of legume, but also for each type of mineral element. These facts are important for germ development but also for food consumers which are interested for healthy ingredients for consumption.

3. For all the analyzed samples, potassium decreases during the germination period whereas calcium increases in a lowest amount of $7.5 \%$ for beans and in a highest amount for chickpeas (almost six times) in the four day of germination. Regarding the other minerals elements analyzed (sulf, phosphor, iron, magnesium, zinc, manganese) they presented different variations during the germination period. The sulf presented higher values in the four day of germination for all the analyzed legumes types except chickpeas for which it decreases with $5.15 \%$. The phosphor decreases for all legumes types except lentil for which increases with $25.87 \%$. The iron decreases for soy, chickpea, lupin and increases for lentil and beans in the four day of germination. In general, zinc decreases for all analyzed samples during the germination period except lupine of which value increases with $50 \%$. Manganese was not detected in lentil and beans meaning that in these legumes types were of a very low concentration. This mineral did not vary during germination in soy seeds but increases in lupine with $9.61 \%$ and decreases in chickpeas with $20.43 \%$ in the four day of germination period.

Acknowledgments: „This work was supported by a grant of the Romanian Ministry of Education and Research, CNCS - UEFISCDI, project number PN-III-P1-1.1-TE-2019-0892, within PNCDI III".

\section{References}

1. Han C., Yang, P. (2015), Studies on the molecular mechanisms of seed germination, Proteomics 15, pp. 1671-1679.

2. Tuan P. A., Sun M., Nguyen T. N., Park S., Ayele B. T. (2019), 1 - Molecular mechanisms of seed germination, Sprouted Grains: Nutritional Value, Production and Applications, pp. 1-24.

3. Liu H., Li H., Yang G., Yuan G., Ma Y., Zhang T. (2021), Mechanism of early germination inhibition of fresh walnuts (Juglans regia) with gamma radiation uncovered by transcriptomic profiling of embryos during storage, Postharvest Biology and Technology, pp. 111380. 
4. Borzouei A., Kafi M., Khazaei H., Naseriyan B., Majdabadi A. (2010), Effects of gamma radiation on germination and physiological aspects of wheat (Triticum aestivum L.) seedlings, Pakistan Journal of Botany, pp. 2281-2290.

5. Oghbaei M., Prakash J. (2020), Effect of dehulling and cooking on nutritional quality of chickpea (Cicer arietinum L.) germinated in mineral fortified soak water, Journal of Food Composition and Analysis, 94, 103619.

6. Pjak P., Socha R., Broniek J., Królikowska K., Fortuna T. (2019), Antioxidant properties, phenolic and mineral composition of germinated chia, golden flax, evening primrose, phacelia and fenugreek, Food Chemistry, 275, pp. 69-76.

7. Venkidasamy B., Selvaraj D., Nile A. S., Ramalingam S., Kai G. Nile S. H. (2019), Indian pulses: A review on nutritional, functional and biochemical properties with future perspectives, Trends in Food Science \& Technology, 88, pp. 228-242.

8. Chinma C. E., Abu J. O., Asikwe B. N., Subday T., Adebo O. A. (2021), Effect of germination on the physicochemical, nutritional, functional, thermal properties and in vitro digestibility of Bambara groundnut flours, LWT - Food Science and Technology, $140,110749$.

9. Ge X., Saleh A. S. M., Jing L., Zhao K., Su C., Zhang B., Zhang Q., Li W. (2021), Germination and drying induced changes in the composition and content of phenolic compounds in naked barley, Journal of Food Composition and Analysis, 95, 103594.

10. Pilco-Quesada S., Tian Y., Yang B., Repo-Carrasco-Valencia R., Suomela J.P. (2020), Effects of germination and kilning on the phenolic compounds and nutritional properties of quinoa (Chenopodium quinoa) and kiwicha (Amaranthus caudatus), Journal of Cereal Science, 94, 102996.

11. Chu C., Du Y,m Yu X., Shi J., Yuan X., Liu X., Liu Y., Zhang H., Zhang Z., Yan N. (2020), Dynamics of antioxidant activities, metabolites, phenolic acids, flavonoids, and phenolic biosynthetic genes in germinating Chinese wild rice (Zizania latifolia), Food Chemistry, 318, 126483.

12. Aisyah S., Vincken J-P., Andini S., Mardiah Z., Gruppen H. (2016), Compositional changes in (iso)flavonoids and estrogenic activity of three edible Lupinus species by germination and Rhizopus-elicitation, Phytochemistry, 122, pp. 65-75.

13. Kamjijam B., Bednarz H., Suwannaporn P., Na Jom K., Niehaus K. (2020), Localization of amino acids in germinated rice grain: Gamma-aminobutyric acid and essential amino acids production approach, Journal of Cereal Science, 93, 102958.

14. Yang Q., Luo Y., Wang H., Li J., Gao X., Gao J., Feng B. (2021), Effects of germination on the physicochemical, nutritional and in vitro digestion characteristics of flours from waxy and nonwaxy proso millet, common buckwheat and pea, Innovative Food Science and Emerging Technologies, 67, 102586.

15. El-Suhaibani M., Ahmed M. A., Osman M. A. (2020), Study of germination, soaking and cooking effects on the nutritional quality of goat pea (Securigera securidaca L.), Journal of King Saud University - Science, 32, pp. 2029-2033.

16. Huang G., Cai W., Xu B. (2017), Improvement in beta-carotene, vitamin B2, GABA, free amino acids and isoflavones in yellow and black soybeans upon germination, $L W T$ - Food Science and Technology, 75, pp. 488-496.

17. Kim M. Y., Lee S. H., Jang G.Y., Li M., Lee Y. R., Lee J., Jeong H.S. (2017), Changes of phenolic-acids and vitamin E profiles on germinated rough rice (Oryza sativa L.) treated by high hydrostatic pressure, Food Chemistry, 217, pp. 106-111.

18. Ma M., Zhang h., Xie Y., Yang M., Tang J., Wang P., Yang R. (2020), Response of nutritional and functional composition, anti-nutritional factors and antioxidant activity 
in germinated soybean under UV-B radiation, LWT - Food Science and Technology, $118,108709$.

19. Su C., Saleh A.S.M., Zhang B., Feng D., Zhao J., Guo Y., Zhao J., Li W., Yan W. (2020), Effects of germination followed by hot air and infrared drying on properties of naked barley flour and starch, International Journal of Biological Macromolecules, 165, pp. 2060-2070.

20. Liu Y., Su C., Saleh A.S.M., Wu H., Zhao K., Zhang G., Jiang H., Yan W., Li W. (2020), Effect of germination duration on structural and physicochemical properties of mung bean starch, International Journal of Biological Macromolecules, 154, pp. 706 713.

21. Osnaya-Gutiérrez L.J., Hernández-Uribe J.P., Castro-Rosas J., Román-Gutiérrez A.D., Camacho-Díaz B.H., Palma-Rodríguez H.M., Rodríguez-Marín M.L., Hernández-Ávila J., Guzmán-Ortiz F.A. (2020), Influence of germination time on the morphological, morphometric, structural, and physicochemical characteristics of Esmeralda and Perla barley starch, International Journal of Biological Macromolecules, 149, pp. 262-270.

22. Atudorei D, Codină G.G. (2020), Perspectives on the Use of Germinated Legumes in the Bread Making Process, A Review, Applied Sciences, 10 (18), pp. 6244.

23. Ghavidel R.A., Prakash J. (2007), The impact of germination and dehulling on nutrients, antinutrients, in vitro iron and calcium bioavailability and in vitro starch and protein digestibility of some legume seeds, LWT - Food Science and Technology, 40, pp. 12921299.

24. Chinma C.E., Adedeji O.E., Etim I.I., Aniaka G.I., Mathew E.O., Ekeh U.B., Anumba N.L. (2020) Physicochemical, nutritional, and sensory properties of chips produced from germinated African yam bean (Sphenostylis stenocarpa), LWT - Food Science and Technology, 136, 110330.

25. Kalpanadevi V., Mohan V.R. (2013), Effect of processing on antinutrients and in vitro protein digestibility of the underutilized legume, Vigna unguiculata (L.) Walp subsp. unguiculata, LWT - Food Science and Technology, 51, pp. 455-461.

26. Millar K.A., Barry-Ryan C., Burke R., McCarthy S., Gallagher E. (2019), Dough properties and baking characteristics of white bread, as affected by addition of raw, germinated and toasted pea flour, Innovative Food Science and Emerging Technologies, $56,10218189$.

27. Hefni M., Witthöft C.M., (2011), Increasing the folate content in Egyptian baladi bread using germinated wheat flour, LWT - Food Science and Technology, 44, pp. 706-712.

28. Guardado-Félix D., Lazo-Vélez M.A., Pérez-Carrillo E., Panata-Saquicili D.E., SernaSaldívar S.O. (2020), Effect of partial replacement of wheat flour with sprouted chickpea flours with or without selenium on physicochemical, sensory, antioxidant and protein quality of yeast-leavened breads, LWT - Food Science and Technology, 129, 109517.

29. Eker M.E., Karakaya S. (2020), Influence of the addition of chia seeds and germinated seeds and sprouts on the nutritional and beneficial properties of yogurt, International Journal of Gastronomy and Food Science, 22, 100276.

30. Ujiroghene O.J., Liu L., Zhang s., Lu J., Zhang C., Lv J., Pang X., Zhang M. (2019), Antioxidant capacity of germinated quinoa-based yoghurt and concomitant effect of sprouting on its functional properties, LWT - Food Science and Technology, 116, 108592.

31. Cáceres P.J., Peñas A., Martínez-Villaluenga C., García-Mora P., Frías J. (2019), LWT - Food Science and Technologyi, 99, pp. 306-312. 
32. Hidalgo A., Šaponjac V.T., Ćetković G., Šeregelj V., Čanadanović-Brunet J., Chiosa D., Brandolini A. (2019), Antioxidant properties and heat damage of water biscuits enriched with sprouted wheat and barley, LWT - Food Science and Technology, 114, 108423.

33. Cairano M., Galgano F., Tolve R., Caruso M.C., Condelli N. (2018), Focus on gluten free biscuits: Ingredients and issues. Review, Trends in Food Science \& Technology, 81, pp. 203-212.

34. Jan R., Saxena D.C., Singh S. (2016), Physico-chemical, textural, sensory and antioxidant characteristics of gluten - Free cookies made from raw and germinated Chenopodium (Chenopodium album) flour, LWT - Food Science and Technology, 71, pp. 281-287.

35. Chauhan A., Saxena D.C., Singh S. (2015), Total dietary fibre and antioxidant activity of gluten free cookies made from raw and germinated amaranth (Amaranthus spp.) flour, LWT - Food Science and Technology, 63, pp. 939-945.

36. Chung H.J., Cho A., Lim S.T. (2014), Utilization of germinated and heat-moisture treated brown rices in sugar-snap cookies, LWT - Food Science and Technology, 57, pp. 260-266.

37. Sharma S., Saxena D.C., Riar C.S. (2016), Nutritional, sensory and in-vitro antioxidant characteristics of gluten free cookies prepared from flour blends of minor millets, Journal of Cereal Science, 72, pp. 153-161.

38. Sawhma, J.T., Mohler, C.L. (2002), Evaluating seed viability by an unimbibed seed crush test in comparison with the tetrazolium Test, Weed Technology 16(4), pp. 781786

39. ISTA (2006), ISTA Handbook on Seedling Evaluation. International Seed Testing Association; ISTA: Bassersdorf, Switzerland.

40. Banashree, S., Nirmali G. (2015), Germination and seedling growth of Okra (Abelmoschus esculentus L.) as influenced by organic amendments, Cogent Food \& Agriculture, 1, pp. 1-6

41. Codină, G.G., Mironeasa, S. (2018), Bread quality and alveograph rheological properties of composite flour made from flaxseed and 650 type wheat of strong quality for bread making, International Journal of Food Engineering, 4 (2), pp. 117-121

42. Ciocan, M., Dabija, A., Codină, G.G. (2020), Effect of some unceonventional ingredients on the production of black beer, Ukranian Food Journal, 9 (2), 322-331

43. Hung P.H., Yen N.T.h., Phi N.T.L., Tien N.P. H., Trung N.T.T. (2020), Nutritional composition, enzyme activities and bioactive compounds of mung bean (Vigna radiata L.) germinated under dark and light conditions, LWT - Food Science and Technology, 133,110100 .

44. Chen Z., Wang P., Weng Y., Ma Y., Gu Z., Yang R. (2017), Comparison of phenolic profiles, antioxidant capacity and relevant enzyme activity of different Chinese wheat varieties during germination, Food Bioscience, 20, pp. 159-167.

45. Cho D.H., Lim S.T. (2018), Changes in phenolic acid composition and associated enzyme activity in shoot and kernel fractions of brown rice during germination, Food Chemistry, 256, pp. 163-170.

46. Sokrab A.M., Ahmed I.A.M., Babiker E.E., (2012), Effect of germination on antinutritional factors, total, and extractable minerals of high and low phytate corn (Zea mays L.) genotypes, Journal of the Saudi Society of Agricultural Sciences, 11, pp. 123128.

47. Alkaltham M.S., Salamatullah A.M., Özcan M.M., Uslu N., Hayat K. (2020), The effects of germination and heating on bioactive properties, phenolic compounds and 
mineral contents of green gram seeds, LWT - Food Science and Technology, 134, 110106.

48. Badau M.H., Nkama I., jideeani I.A. (2005), Phytic acid content and hydrochloric acid extractability of minerals in pearl millet as affected by germination time and cultivar, Food Chemistry, 92, pp. 425-435.

49. Guimarães B., Polachini t.C., Augusto P.E., Telis-Romero J. (2020), ltrasound-assisted hydration of wheat grains at different temperatures and power applied: Effect on acoustic field, water absorption and germination, Chemical Engineering \& Processing: Process Intensification, 155, 108045.

50. Biazus J.P.M., Santana J.C.C., Souza R.R., Tambourgi E.B. (2006), Caracterização da atividade amilásica do malte de milho (Zea mays Zea mays L.), Acta Scientiarum. Technology, 28, pp. 13-19.

51. Jia Y., Li W. (2018), Phospholipase D antagonist 1-butanol inhibited the mobilization of triacylglycerol during seed germination in Arabidopsis, Plant Diversity, 40, pp. 292 298.

52. Mandal R., Dutta G. (2020), From photosynthesis to biosensing: Chlorophyll proves to be a versatile molecule, Sensors International, 1, 100058.

53. Agathokleous E., Feng Z., Peñuelas J. (2020), Chlorophyll hormesis: Are chlorophylls major components of stress biology in higher plants?, Science of the Total Environment, $726,138637$.

54. Shekhar V., Stöckle D., Thellmann M., Vermeer J.E.M. (2018), Chapter Three - The role of plant root systems in evolutionary adaptation, Current Topics in Developmental Biology, 131, pp. 55-80.

55. Yamada M., Sawa S. (2013), The roles of peptide hormones during plant root development, Current Opinion in Plant Biology, 16 (1), pp. 56-61.

56. Liang J., Han B.Z., Nout m.J.R., Hamer R.J. (2008), Effects of soaking, germination and fermentation on phytic acid, total and in vitro soluble zinc in brown rice, Food Chemistry, 110, pp. 821-828.

57. Kaur M., Asthir B., Mahajan G. (2017), Variation in Antioxidants, Bioactive Compounds and Antioxidant Capacity in Germinated and Ungerminated Grains of Ten Rice Cultivars, Rice Science, 24 (6), pp. 349-359.

58. Kumari A., Rosenkranz T., Kayastha A., Fitter J. (2010), The effect of calcium binding on the unfolding barrier: A kinetic study on homologous $\alpha$-amylases, Biophysical Chemistry, 151, pp. 54-60.

59. Kumari A., Singh V.K., Fitter J, Polen T., Kayastha A.M. (2010), $\alpha$-Amylase from germinating soybean (Glycine max) seeds - Purification, characterization and sequential similarity of conserved and catalytic amino acid residues, Phytochemistry, 71, pp. $1657-1666$.

60. Rogers J.C. (1985), Conserved amino acid sequence domains in alpha-amylases from plants, mammals, and bacteria, Biochemical and Biophysical Research Communications, 128, pp. 470-476.

61. Stein E.A., Fischer E.H. (1958), The resistance of alpha-amylases towards proteolytic attack, Journal of Biological Chemistry, 232, pp. 867-879.

62. Campos H., Trejo C., Peña-Valdivia C.B., García-Nava R., Conde-Martínez R.V., Cruz-Ortega R. (2020), Water availability effects on germination, membrane stability and initial root growth of Agave lechuguilla and A. salmiana, Flora, 268, 151606.

63. Andrade J.L., Cervera J.C., Graham E.A. (2009), Microenvironments, water relations and productivity of CAM plants, Perspectives in Biophysical Plant Ecophysiology, pp. 95-120. 
64. Singh S.P., Schwan A.L. (2019), 4.18 - Sulfur Metabolism in Plants and Related Biotechnologies, Comprehensive Biotechnology, 4, pp. 221-236.

65. Park S.J., Lee M.J., Choi Y.J., Yun Y.R., Lee M.A., Oh S.J., Park S.H. (2020), Improvement of sulfur compounds in broccoli sprouts by methionine loaded polyvinyl alcohol-sodium alginate hydrogels for application in Kimchi, LWT-Food Science and Technology, 118, 108745.

66. Kestwal R.M., Lin J.C., Bagal-Kestwal D., Chiang B.H. (2011), Glucosinolates fortification of cruciferous sprouts by sulphur supplementation during cultivation to enhance anti-cancer activity, Food Chemistry, 126, pp. 1164-1171.

67. Parcell S. (2002), Sulfur in human nutrition and applications in medicine, Alternative Medicine Review, 7, pp. 22-44.

68. Ali V., Khajuria M., Bhat R., Rashid A., Faiz S. (2021), Comparative phytochemical analysis of Lepidium latifolium L. sprouts from Ladakh Himalayas suggest a novel combination of 2-propenyl and benzyl glucosinolate, LWT - Food Science and Technology, 13, 110713.

69. Bains K., Uppal V., Haur H. (2014), Optimization of germination time and heat treatments for enhanced availability of minerals from leguminous sprouts, Journal of Food Science and Technology, 51, pp. 1016-1020.

70. Nkhata S.G., Ayua E., Kamau E.h., Shingiro J.B. (2018), Fermentation and germination improve nutritional value of cereals and legumes through activation of endogenous enzymes, Food Sciences and Nutrition, 6, pp. 2446-2458.

71. Ohanenye I.C., Tsopmo A., Ejike C.E.C.G., Udenigwe C.C. (2020), Germination as a bioprocess for enhancing the quality and nutritional prospects of legume proteins, Trends in Food Science \& Technology, 101, pp. 213-222.

72. Jimenez M.D., Lobo M., Sammán N. (2019), Influence of germination of quinoa (Chenopodium quinoa) and amaranth (Amaranthus) grains on nutritional and technofunctional properties of their flours, Journal of Food Composition and Analysis, 84, 103290.

73. Maetens E., Hettiarachchy N., Dewettinck K., Horax R., Moens K., Moseley D.O. (2017), Physicochemical and nutritional properties of a healthy snack chip developed from germinated soybeans, LWT - Food Science and Technology, 84, pp. 505-510.

74. Pongrac P., Potisek M., Fraś A., Likar M., Budič B., Myszka K., Boros D., Nečemer M., Kelemen M., Vavpetič P., Pelicon p., Vogel-Mikuš K., Regvar M., Kreft I. (2016), Composition of mineral elements and bioactive compounds in tartary buckwheat and wheat sprouts as affected by natural mineral-rich water, Journal of Cereal Science, 69, pp. $9-16$.

75. Ouazaz R., Sistani N., Mentreddy S., Wu Y. (2018), Mineral Content and Phytochemical Profile of Mungbean Sprouts and Dry Seeds of Five Mungbean Varieties, Journal of the Academy of Nutrition and Dietetics, 118 (10), pp. 149.

76. Pongrac P., Vogel-Mikuš K., Potisek M., Kovačec E., Budič B., Kump P., Regvar M., Kreft I. (2016), Mineral and Trace Element Composition and Importance for Nutritional Value of Buckwheat Grain, Groats, and Sprouts, Molecular Breeding and Nutritional Aspects of Buckwheat, pp. 261-271.

77. Özcan M., Juhaimi F. (2014), Effect of sprouting and roasting processes on some physico-chemical properties and mineral contents of soybean seed and oils, Food Chemistry, 154, pp. 337-342. 